\title{
FORMULASI HUKUM, LANGKAH MENGATASI PROBLEMATIKA EKSEKUSI HAK TANGGUNGAN DALAM PENYELESAIAN KREDIT MACET
}

\author{
Agus Susila \\ Atma Jaya Yogyakarta \\ alfino.osila@yahoo.com
}

\begin{abstract}
Article with the title aims to determine the Legal Formulation And Steps To Overcome The Problems in Execution Of Mortgage In Settling Of Bad Credit. This research is a normative research with secondary data consisting of primary law sources and secondary law sources. How to obtain data using literature study and interview. Primary legal sources and secondary legal sources were analyzed using the legal Theory approach. The process of deductive thinking to draw conclusions. The results of this study indicate that; The position of the creditor as the holder of the mortgage on the guarantee of the Hak Guna Bangunan (SHGB) Certificate whose term or period of validity of the $S H G B$ has expired and has not been renewed, causing the mortgage inherent in the SHGB to be void and the Debtor has defaulted to the Creditor. So required Legal Formulation And Steps To Overcome The Problems in Executions Of Mortgage In Settling Bad Credit.
\end{abstract}

Keywords : Legal Formulation, Executions Of Mortgage, bad credit

\begin{abstract}
Abstrak
Artikel ini bertujuan untuk mengetahui dan menentukan Formulasi Hukum Dan Langkah-Langkah Untuk Mengatasi Problematika Eksekusi Hak Tanggungan Dalam Penyelesaian Kredit Macet. Penelitian ini merupakan penelitian normatif Sumber data berupa data sekunder yang terdiri atas bahan hukum primer dan bahan hukum sekunder. Hasil penelitian ini menunjukkan bahwa; Kedudukan Kreditur sebagai Pemegang Hak Tanggungan atas jaminan Sertifikat Hak Guna Bangunan (SHGB) yang masa atau jangka waktu berlakunya SHGB tersebut telah berakhir dan belum diperpanjang sehingga menyebabkan Hak Tanggungan yang melekat dalam SHGB tersebut menjadi hapus dan Debitur telah Wanprestasi kepada Kreditur. Sehingga diperlukan Formulasi Hukum Dan Langkah-Langkah Untuk Mengatasi Problematika Eksekusi Hak Tanggungan Dalam Penyelesaian Kredit Macet.
\end{abstract}

Kata Kunci: formulasi hukum, eksekusi hak tanggungan, kredit macet

\section{A. Pendahuluan}

\section{Latar Belakang Permasalahan}

Negara Indonesia adalah negara hukum, dan prinsip negara hukum menuntut adanya jaminan kesederajatan bagi setiap orang di hadapan hukum (equality before the law). Undang-Undang Dasar Tahun 1945 menentukan bahwa setiap orang berhak atas pengakuan, jaminan, perlindungan, dan kepastian hukum yang adil serta perlakuan yang sama di hadapan hukum.

Landasan yuridis konstitusional dalam Pasal 33 ayat (3) Undang-Undang Dasar 1945 telah menyebutkan bahwa bumi dan air serta kekayaan alam yang terkandung di dalamnya dikuasai oleh Negara dan dipergunakan untuk sebesar-besarnya kemakmuran rakyat. Dari ketentuan ini dapat tercermin bahwa bumi, air serta kekayaan alam yang terkandung didalamnya adalah dikuasai oleh Negara dan dipergunakan untuk mencapai sebesarbesarnya kemakmuran rakyat Indonesia.

Oleh karena itu, setiap kegiatan manusia maupun kegiatan ekonomi yang berkaitan dengan hal-hal diatas dan yang menunjang pembangunna nasional perlu diatur oleh Negara. Peranan hukum dan peraturan perundang-undangan ini sangat penting dan 
dengan bertambah dan meningkatnya pembangunan nasional pada bidang ekonomi nasional, sangat dibutuhkan penyediaan dana yang cukup besar, sehingga memerlukan lembaga keuangan yang kuat dan mampu memberi kepastian hukum bagi pihak-pihak yang berkepentingan, yang dapat mendorong peningkatan partisipasi masyarakat dalam pembangunan untuk mewujudkan masyarakat yang sejahtera, adil dan makmur berdasarkan Pancasila dan Undang-Undang Dasar Tahun 1945.

Bank selaku pemberi kredit menghadapi resiko yaitu tidak kembalinya dana yang telah dicairkan kepada debitur atau kredit yang telah disalurkan kepada debitur dan untuk menghindari atau untuk meminimalkan resiko tersebut maka bank perlu melakukan pencegahan dengan cara meminta debitur agar memberikan jaminan berupa barang jaminan baik benda bergerak maupun benda tidak bergerak, untuk dapat dijadikan jaminan dalam pemberian kredit.

Ada beberapa upaya yang dilakukan pihak bank terhadap benda-benda jaminan sebagai suatu perlindungan bagi bank dalam hal debitur mengalami masalah dalam pengembalian kreditnya atau kredit macet, misalnya menggunakan hak tanggungan sebagai upaya untuk eksekusi jaminan dalam upaya pelunasan fasilitas kredit di bank. Hal ini berarti setiap debitur yang akan menerima fasilitas kredit di bank harus melalui prosedur yang ada tentunya dengan perjanjian tambahan sebagai jaminan untuk pelunasannya.

Terbentuknya Undang-undang Nomor 4 Tahun 1996 maka ketentuan hipotek, dan Credietverband yang terdapat dalam BW menjadi tidak berlaku lagi sebagai lembaga jaminan. Hal ini ditegaskan dalam Pasal 29 Undang-Undang Nomor 4 Tahun 1996, oleh karena itu lembaga jaminan atas tanah berlaku ketentuan hak tanggungan yaitu yang diatur dalam Undang-Undang Nomor 4 Tahun 1996 Tentang Hak Tanggungan.

Definisi Hak Tanggungan terdapat dalam Pasal 1 ayat (1) Undang-Undang Nomor 4 Tahun 1996 tentang Hak Tanggungan. Di dalam Pasal 1 ayat (1) Undang-undang tersebut ditentukan bahwa;

"Hak Tanggungan adalah hak jaminan yang dibebankan pada hak atas tanah sebagaimana dimaksud dalam Undang-undang Nomor 5 Tahun 1960 tentang Peraturan Dasar Pokokpokok Agraria, berikut atau tidak berikut benda-benda lain yang merupakan satu kesatuan dengan tanah itu, untuk pelunasan hutang tertentu, yang memberikan kedudukan yang diutamakan kepada kreditur tertentu terhadap kreditur-kreditur lain."

Ketentuan Pasal 20 Undang-Undang Nomor 4 Tahun 1996 mengatur tentang Eksekusi Hak Tanggungan dan memberikan jaminan bagi Bank atas fasilitas kredit seorang debitur dan memberikan hak utama (hak preferen) kepada Bank untuk didahulukan dari kreditur-kreditur lain dalam hal debitur mengalami Wanprestasi/Cidera Janji.

Dalam pelaksanaan Eksekusi Hak Tanggungan terhadap jaminan Debitur yang mengalami Wanprestasi/Cidera Janji sering dijumpai adanya hambatan-hambatan dalam pelaksanaannya. Dalam praktek perbankan masih ditemukan adanya hambatan lain selain dalam penelitian yang dilakukan oleh Imma Indra Dewi dan Iswantiningsih dalam Laporan Penelitian Fakultas Hukum, Univesitas Atma Jaya Yogyakarta, tahun 2009, dalam penelitiannya tentang; "Penyelesaian Hambatan Dalam Eksekusi Hak Tanggungan Oleh Kantor Pelayanan Kekayaan Negara Dan Lelang Yogyakarta”,

Dan permasalahan yang lain yang dimaksud dengan penelitian yang berkaitan dengan Kedudukan Kreditur sebagai Pemegang Hak Tanggungan atas agunan Sertifikat Hak Guna Bangunan (SHGB) yang masa atau jangka waktu berlakunya SHGB tersebut telah berakhir dan belum diperpanjang sehingga menyebabkan Hak Tanggungan yang melekat dalam SHGB tersebut menjadi hapus dan Debitur telah Wanprestasi kepada Kreditur. Permasalahan tersebut diperlukan formulasi hukum dan langkah-langkah untuk mengatasi problematika eksekusi hak tanggungan dalam penyelesaian kredit macet.

Dalam mengatasi problematika dalam pelaksanaan Eksekusi Hak Tanggungan di atas terhadap debitur yang mengalami Wanprestasi/Cidera Janji yang menyebabkan kredit macet sangat diperlukan formulasi 
hukum dan langkah-langkah yang tepat yang harus ditempuh oleh kreditur dalam proses penyelesaian dan pengembalian dana dari debitur yang bersangkutan agar tidak merugikan kreditur.

Berdasarkan Latar Belakang Masalah di atas, maka dapat diambil permasalahan dengan pembatasan Hak Tanggungan telah hapus dikarenakan jangka waktu hak dalam Sertifikat Hak Guna Bangunan (SHGB) telah berakhir dan belum dilakukan perpanjangan hak dalam Sertifikat Hak Guna Bangunan (SHGB) yang dimaksud dan debitur telah macet, sebagai berikut:

Bagaimana formulasi hukum dan langkah-langkah untuk mengatasi problematika eksekusi hak tanggungan dalam penyelesaian kredit macet?

\section{Metode Penelitian}

Jenis Penelitian ini adalah penelitian hukum normatif. Sumber data berupa Bahan Hukum Primer dan Bahan Hukum Sekunder. Cara peroleh data dengan Studi Kepustakaan dan Wawancara. analisis yang dgunakan adalah analisis kualitatif. Kesimpulan diambil dengan menggunakan metode berfikir deduktif. Pendekatan yang dipergunakan adalah pendekatan teori hukum, yakni teori idée des rechts (keadilan, kepastian dan kemanfaatan).

\section{B. Hasil Penelitian dan Pembahasan Pembahasan}

Kajian kasus dalam Putusan Pengadilan Negeri Sleman Nomor 185 / Pdt. G/2015/ PN.SMN tanggal 5 April 2016, berkaitan dengan formulasi hukum dan langkahlangkah yang dilakukan PENGGUGAT Kreditur PT. BANK PAN INDONESIA Tbk. Kantor Cabang Yogyakarta untuk mengatasi problematika eksekusi hak tanggungan dalam penyelesaian kredit macet, yang menjadi persoalan dalam penelitian ini adalah dalam menjamin pelunasan utang Debitur kepada Kreditur, terhadap jaminan Sertipikat Hak Guna Bangunan Nomor 00925/Maguwoharjo dengan Surat Ukur No 00176 tgl 02/06/2009 luas $200 \mathrm{~m} 2$ atas nama pemegang hak SUDIYANTO (TERGUGAT), yang telah diikat dan dibebani dengan Hak Tanggungan sebagaimana termuat dalam Sertipikat Hak
Tanggungan Nomor 1483/2010 Peringkat I tanggal 23-03-2010 nama pemegang Hak Tanggungan PT. BANK PAN INDONESIA Tbk. Kantor Cabang Yogyakarta bahwa masa berlakunya Sertifikat Hak Guna Bangunan tersebut telah berakhir haknya pada tanggal 20 Februari 2011 dan belum dilakukan perpanjangan oleh Debitur.

Suatu kewajiban dalam perjanjian dinamakan prestasi bagi debitur, sedangkan bagi kreditur hal tersebut merupakan hak. Tujuan dari suatu perjanjian adalah untuk terbentuknya, berubahnya, atau berakhirnya suatu perikatan. Perjanjian tersebut mewajibkan kepada para pihak untuk memberikan sesuatu, berbuat sesuatu, atau tidak berbuat sesuatu (prestasi) .

Tidak dilaksanakannya segala kewajiban pembayaran hutang dari TERGUGAT debitur SUDIYANTO kepada PENGGUGAT Kreditur PT. BANK PAN INDONESIA Tbk. Kantor Cabang di Yogyakarta dan tidak dilakukan perpanjangan hak atas jaminan Sertifikat Hak Guna Bangunan Nomor 00925/Maguwoharjo tersebut diatas yang telah berakhir haknya pada tanggal 20 Februari 2011, hal ini telah membuktikan adanya itikad yang tidak baik dari Debitur SUDIYANTO.

Sebelum dilakukannya perpanjangan jangka waktu masa berlakunya hak Sertifikat $\mathrm{Hak}$ Gun a B g un a n omor 00925/Maguwoharjo yang telah habis masa berlaku haknya, pada tanggal 20 Februari 2011 maka status kepemilikan Sertifikat Hak Guna Bangunan Nomor 00925/Maguwoharjo tersebut kembali kepada tanah negara dan dikuasai oleh negara. Itikad yang tidak baik dari Debitur SUDIANTO yang tidak mau melakukan perpanjangan Sertifikat Hak Guna Bangunan yang dimaksud tersebut dalam penguasaan negara.

Maria S.W. Sumardjono, dalam bukunya Kebijakan Pertanahan Antara Regulasi dan Implementasi ditegaskan, "Dengan demikian maka yang disebut tanah negara adalah tanahtanah yang tidak dilekati dengan suatu hak, yakni hak milik, hak guna usaha, hak guna bangunan, hak pakai atas tanah Negara, hak pengelolaan serta tanah ulayat dan tanah wakaf." Adapun ruang lingkup tanah negara meliputi juga : 
1. tanah-tanah yang diserahkan secara suka rela oleh pemiliknya;

2. tanah-tanah hak yang berakhir jangka waktunya dan tidak diperpanjang lagi;

3. tanah-tanah yang pemegang haknya meninggal dunia tanpa ahli waris;

4. tanah-tanah yang diterlantarkan; dan

5. tanah-tanah yang diambil untuk kepentingan umum sesuai dengan tata cara pencabutan hak yang diatur dalam Undang-Undang Nomor 20 Tahun 1961 dan pengadaan tanah yang diatur dalam Keppres Nomor 55 Tahun 1993.

Formulasi hukum PENGGUGAT Kreditur PT. BANK PAN INDONESIA Tbk. Kantor Cabang di Yogyakarta dalam mengatasi problematika eksekusi hak tanggungan dalam penyelesaian kredit macet adalah menghidupkan kembali atau melakukan perpanjangan jangka waktu masa berlakunya hak dalam Sertifikat Hak Guna Bangunan Nomor 00925/Maguwoharjo yang telah habis masa berlaku haknya, pada tanggal 20 Februari 2011 dengan melalui gugatan ke Pengadilan Negeri Kabupaten Sleman untuk mendapatkan Putusan Sertifikat Hak Guna Bangunan yang dimaksud dapat diperpanjang.

Gugatan dari PENGGUGAT Kreditur PT. BANK PAN INDONESIA Tbk. Kantor Cabang di Yogyakarta telah dimenangkan pihak PENGGUGAT Kreditur PT. BANK PAN INDONESIA Tbk. Kantor Cabang di Yogyakarta dan diputuskan oleh Majels Hakim Pengadilan Negeri Sleman sebagaimana dalam Putusan Majelis Hakim $\mathrm{P}$ e $\mathrm{ngadilan} \mathrm{N}$ e g e r i S l e m a n Nomor185/Pdt.G/2015/PN.Smn, tanggal 5 April 2016, yang memutus perkara tersebut seperti dalam putusan khususnya pada nomor 4 (empat), sebagai berikut:

(4) Menetapkan secara hukum agar terhadap Sertipikat Hak Guna Bangunan Nomor 00925/Maguwoharjo dengan Surat Ukur No 00176 tanggal 02/06/2009 luas 200 $\mathrm{m} 2$ atas nama pemegang hak SUDIYANTO (TERGUGAT), dapat diperpanjang melalui TURUT TERGUGAT (Kantor Pertanahan Kabupaten Sleman), sehingga memperoleh hak perpanjangan sebagaimana mestinya.

Berkaitan dengan Putusan Majelis Hakim Pengadilan Negeri Sleman seperti dalam pada nomor 4 (empat) di atas disebutkan "Menetapkan secara hukum agar terhadap Sertipikat Hak Guna Bangunan Nomor 00925/Maguwoharjo dengan Surat Ukur No 00176 tanggal 02/06/2009 luas $200 \mathrm{~m} 2$ atas nama pemegang hak SUDIYANTO (TERGUGAT), dapat diperpanjang melalui TURUT TERGUGAT (Kantor Pertanahan Kabupaten Sleman), sehingga memperoleh hakperpanjangan sebagaimana mestinya,"

Dalam penelitian ini Putusan Majelis Hakim Pengadilan Negeri Sleman di atas Majelis Hakim telah mempertimbangkan dan didasarkan pada peraturan perundangundangan yang berlaku, yaitu:

1. Berdasarkan ketentuan Pasal 125 Peraturan Menteri Negara Agraria / Kepala Badan Pertanahan Nasional Nomor 3 Tahun 1997 tentang Ketentuan Pelaksanaan Peraturan Pemerintah Nomor 24 Tahun 1997 tentang Pendaftaran Tanah, pencatatat perubahan data pendaftaran tanah berdasarkan Putusan Pengadilan dilakukan setelah Kantor Pertanahan menerima salinan resmi Putusan Pengadilan yang telah mempunyai kekuatan hukum tetap.

2. TURUT TERGUGAT dapat memproses pencatatan perubahan data pendaftaran tanah berdasarkan Putusan Pengadilan yang telah mempunyai kekuatan hukum tetap, apabila didaftarkan pada loket pelayanan pada Kantor Pertanahan Kabupaten Sleman dengan melampirkan persyaratan sesuai ketentuan Peraturan Kepala Badan Pertanahan Nasional Nomor 1 Tahun 2010 serta membayar biaya sesuai Peraturan Pemerintah Nomor 13 Tahun 2010.

Putusan Majelis Hakim Pengadilan Negeri Sleman dalam memutuskan perkara di atas dalam penelitian ini telah mempertimbangkan tiga aspek tujuan hukum yaitu asas kepastian hukum, asas keadilan dan asas kemanfaatan. Seperti yang dikemukakan oleh Sudikno Mertokusumo 
bahwa ketiga asas tersebut harus dilaksanakan secara kompromi, yaitu dengan cara menerapkan ketiga-tiganya secara seimbang atau proporsional sehingga tidak perlu mengikuti asas prioritas sebagaimana Radbrurch, dan penulis sependapat dengan Sudikno Mertokusumo. Selanjutnya bahwa penekanan pada asas kemanfaatan lebih bernuansa ekonomi, dengan dasar pikir bahwa hukum itu ada untuk manusia, sehingga tujuan hukum harus berguna bagi masyarakat untuk mencapai kesejahteraan. Adapun penekanan pada asas kepastian hukum lebih bernuansa pada terciptanya keteraturan dan ketertiban dalam masyarakat.

Idealnya, memang hukum harus mengakomodasi ketiganya. Putusan Majelis Hakim Pengadilan Negeri Sleman Nomor185/Pdt.G/2015/PN.Smn, tanggal 5 April 2016, sedapat mungkin merupakan resultante dari ketiganya. Menurut Aristoteles (sebagaimana dikutip Hyronimus Rhiti, 2011:241) keutamaan yaitu ketaatan terhadap hukum (hukum polis pada waktu itu, tertulis atau tidak tertulis) adalah keadilan. Putusan hakim penekanan pada asas keadilan, berarti hakim harus mempertimbangkan hukum yang hidup dalam masyarakat, yang terdiri dari atas kebiasaan hukum yang tidak tertulis. Dalam hal ini harus dibedakan keadilan menurut individu, kelompok dan masyarkat. Selain itu kedilan dari suatu masyarakat tertentu, belum tentu sama rasa keadilan dengan masyarakat lain. Jadi pertimbangan putusannya, hakim harus mampu menggambarkan hal tersebut, manakala hakim memilih asas keadilan sebagai dasar untuk menjatuhkan putusan.

Menurut Aristoteles menyatakan bahwa ukuran keadilan adalah : 1 . Seseorang tidak melanggar hukum yang berlaku, sehingga keadilan berarti "lawful" yaitu hukum tidak boleh dilanggar dan aturan harus diikuti. Dan 2. Seseorang tidak boleh mengambil lebih dari haknya, sehingga keadilan berarti persamaan hak (equal). Adil dapat berarti menurut hukum, dan apa yang sebanding, yaitu yang semestinya. Sehingga penulis sependapat dengan Aristoteles bahwa sedapat mungkin hakim menggunakan aspek keadilan tetapi keadilan yang menurut hukum.

Dari sisi Kepastian Hukum berkaitan dengan efektivitas hukum. Sebab itu kepastian hukum hanya terjamin, bila pemerintah negara mempunyai sarana-sarana yang secukupnya untuk memastikan peraturan-peraturan yang ada. Menjamin kepastian hukum ini menjadi tugas hukum. Hukum yang berhasil menjamin banyak kepastian dalam hubungan-hubungan kemasyarakat adalah hukum yang berguna.

Berdasarkan pendekatan teori hukum yaitu pendekatan yang digunakan untuk menganalisa secara kritis dalam perspektif interdisipliner, pelbagai aspek perwujudan (fenomena) hukum secara tersendiri atau menyeluruh baik dalam konsepsi teoritis maupun dalam pelaksanaan praktis dengan tujuan memperoleh pengetahuan yang lebih baik dan uraian yang lebih jelas tentang bahan-bahan yuridis, sehingga dapat dijelaskan bahwa putusan hakim merupakan perwujudan hukum dalam pelaksanaan praktek-konkret, adanya kesesuain ini terlihat dalam pertimbangan hukum bagi majelis hakim dalam mengambil putusan dan penulis menggunakan pendekatan teori hukum ini untuk mengkaji dan mengevalusasi Putusan Pengadilan Negeri Sleman Nomor 185/Pdt.G/2015/PN.SMN, tanggal 5 April 2016 yang telah berkekuatan hukum tetap.

Pemberian fasilitas kredit antara debitur (TERGUGAT) dan kreditur (PENGGUGAT) di atas juga telah didasarkan pada:

Perjanjian Kredit yang disepakati dan ditandatangani oleh para pihak sebagaimana dalam Akta Notaris Nomor 19, tanggal 14 Desember 2009 tentang Perjanjian Kredit Pemilikan Rumah yang dibuat oleh dan dihadapan Notaris Triniken Tiyas Tirlin, SH dan untuk menjamin pelunasan hutang debitur sebagaimana dalam Akta Perjanjian Kredit Nomor 19, tanggal 14 Desember 2009 debitur telah memberikan jaminan yaitu Sertipikat Hak Guna Bangunan Nomor 00925/Maguwoharjo dengan Surat Ukur No $00176 \mathrm{tgl}$ 02/06/2009 luas $200 \mathrm{~m} 2$ atas nama pemegang hak SUDIYANTO (TERGUGAT) yang telah diikat dan dibebani dengan Hak Tanggungan sebagaimana termuat dalam Sertipikat Hak Tanggungan Nomor 1483/2010 Peringkat I tanggal 23-03-2010 nama pemegang Hak Tanggungan PT. BANK PAN INDONESIA Tbk. Kantor Cabang 
Yogyakarta.

Lahirnya Perjanjian Kredit menurut Subekti, perjanjian lahir pada saat tercapainya kata sepakat diantara kedua belah pihak. Sehubungan dengan perjanjian kredit berarti perjanjian kredit telah lahir saat tercapai kata sepakat atau saat penandatanganan perjanjian kredit tersebut.(Subekti, 1987:16).

Syarat-syarat sahnya suatu Perjanjian harus memenuhi 4 unsur seperti yang diatur didalam Pasal 1320 KUH Perdata, yaitu;

1. Sepakat mereka yang mengikatkan dirinya.

2. Kecakapan untuk membuat suatu perikatan.

3. Suatu hal tertentu.

4. Suatu sebab yang halal.

Definisi kredit yang terdapat dalam peraturan perundang-undangan didalam Pasal 1 ayat (11) Undang-undang Nomor 10 Tahun 1998 tentang Perbankan, disebutkan bahwa;

"Kredit adalah penyediaan uang atau tagihan yang dapat dipersamakan dengan itu, berdasarkan persetujuan atau kesepakatan pinjam-meminjam antara bank dengan pihak lain yang mewajibkan pihak peminjam untuk melunasi hutangnya setelah jangka waktu tertentu dengan pemberian bunga."

Dan berdasarkan definisi Kredit dan Resiko Kredit terdapat dalamPasal 1 ayat (2) dan (3) Peraturan Otoritas Jasa Keuangan (OJK) Nomor 11/POJK/.03/2005 tentang Ketentuan Kehati-hatian Dalam Rangka Stimulasi Perekonomian Nasional Bagi Bank Umum disebutkan bahwa;

(2) Kredit adalah penyediaan uang atau tagihan yang dapat dipersamakan dengan itu, berdasarkan persetujuan atau kesepakatan pinjam meminjam antara Bank dengan pihak lain yang mewajibkan pihak peminjam untuk melunasi utangnya setelah jangka waktu tertentu dengan pemberian bunga,termasuk:

a. cerukan (overdraft), yaitu saldo negatif pada rekening giro nasabah yang tidak dapat dibayar lunas pada akhir hari;

b. pengambilalihan tagihan dalam rangka kegiatan anjak piutang; dan

c. pengambilalihan atau pembelian kredit dari pihak lain.

(3) Risiko Kredit adalah risiko akibat kegagalan debitur dan/atau pihak lain dalam memenuhi kewajiban kepada Bank.

Definisi Hak Tanggungan terdapat dalam Pasal 1 ayat (1) Undang-Undang Nomor 4 Tahun 1996 tentang Hak Tanggungan. Di dalam Pasal 1 ayat (1) Undang-undang tersebut ditentukan bahwa;

Hak Tanggungan adalah hak jaminan yang dibebankan pada hak atas tanah sebagaimana dimaksud dalam Undangundang Nomor 5 Tahun 1960 tentang Peraturan Dasar Pokok-pokok Agraria, berikut atau tidak berikut benda-benda lain yang merupakan satu kesatuan dengan tanah itu, untuk pelunasan hutang tertentu, yang memberikan kedudukan yang diutamakan kepada kreditur tertentu terhadap krediturkreditur lain.

Ketentuan Pasal 20 Undang-Undang Nomor 4 Tahun 1996 mengatur tentang : Eksekusi Hak Tanggungan dan memberikan jaminan bagi Bank atas fasilitas kredit seorang debitur dan memberikan hak utama (hak preferen) kepada Bank untuk didahulukan dari kreditur-kreditur lain dalam hal debitur mengalami Wanprestasi/Cidera Janji.

\section{Simpulan}

Berdasarkan uraian mengenai pembahasan atas permasalahan tentang, maka dapat ditarik kesimpulan sebagai berikut:

Melakukan perpanjangan Sertifikat Hak Guna Bangunan yang dimaksud dengan langkah-langkah melakukan gugatan melalui pengadilan negeri setempat dalam wilayah hukumnya untuk memperoleh putusan dari Majelis Hakim Pengadilan Negeri setempat dengan putusan Sertifikat Hak Guna Bangunan yang dimaksud dapat diperpanjang.

\section{DAFTAR PUSTAKA}

Arus Akbar Silondae, Wirawan B. Ilyas, Pokok-Pokok Hukum Bisnis, Salemba Empat, Jakarta.

Maria S.W. Sumardjono, (2009) 
Masalah - Masalah Hukum, Jilid 46 No. 1, Januari 2017, Halaman 41-47

Kebijakan Pertanahan Antara Regulasi dan Implementasi, Kompas, Jakarta.

Sudikno Mertokusumo, (2012), Teori Hukum, PT. Cahaya Atma Pustaka, Yogyakarta.

Subekti, (1987) Hukum Perjanjian, Internusa, Jakarta.

Theo Huijbers, (2015), Filsafat Hukum, Ketujubelas, PT. Kanisius, Yogyaka 